\title{
Juice concentrates of edible mushrooms
}

\author{
WANDA WOŹNIAK and EUGENIA SOBKOWSKA
}

\begin{abstract}
WOZNIAK, W. \& SOBKOWSKA, E. 1978: Juice concentrates of edible mushrooms. - Karstenla 18 (suppl.).

Mushroom juice concentrates are refined products, attractive to consumers for their high organoleptic value to be used as an additive to different products and dishes and in the preparation of soups and sauces.

In this investigation Tricholoma equestre, Cantharellus cibarius, Russula alutacea and Armillariella mellea, growing in Polish forests were used for concentrate production. The juice of fresh, frozen or dried fung $i$ was obtained by pressing or extraction, concentrated by vacuum distillation or freezing and stored at $4^{\circ} \mathrm{C}$.

The quality of the juice and of one- and two-component concentrates was determined chemically and organoleptically. Freezing of mushrooms before the juicing step was found to be benefical in chemical and organoleptic evaluation. Concentration by cryoscopic technique allows the juice to retain the original specific taste characteristics. The concentrates of Xerocomus badius and $T$. equestre as well as the combined concentrates containing Xerocomus juice were found to be of high sensory value.
\end{abstract}

W. Wozñiak \& E. Sobkowska, Institute of Food Technology, Agricultural Academu in Poznañ. w. Wo jska Polskiego 31, Poznañ, Poland.

\section{Materials and methods}

Fruit-bodies of Armilzariella melzea (Fr.) Karst., Cantharelius cibarius Fr., Russula alutacea (Fr.) Fr., Tricholoma equestre (L. ex Fr.) Quél, and Xerocomus badius (Fr.) Kühn, were collected from pine woods in western Poland (Poznan and Miedzychod regions) in the autumns of 1973-1977 in 5-40 kg sample lots each. According to Polish Norm $\frac{\mathrm{PN}-76}{\mathrm{R}-78505}$ the mushrooms were of the first quality class.

Dry weight (at $105^{\circ} \mathrm{C}$ ), soluble solids (by refractometer), titrable ard volatile acids (as acetic acid), esters (as ethyl acetate) and Kjeldahl. $\mathrm{N}$ were measured by standard methods. Protein N (with chitin) and $\mathrm{NH}_{2}-\mathrm{N}$ were determined according to Bielozierski (1954). For sensory evaluation the five-unit organoleptic method of Tilgner (1957) was used.

The mushroom juice was obtained in a manual basket press ( $5 \mathrm{~kg}$ capacity) and a pilot plant layer press (Bücher-Guyer AG, TPZ-7, 25-30 kg capacity) after milling of the fresh or frozen fruit-bodies in Rietz disintegrator. T. equestre was classified according to the scheme for combined processing (Sobkowska \& Wokniak 1978) and the broken fruit-bodies were used. The juice was sterilized at $120^{\circ} \mathrm{C}$ for 22 minutes or was directly concentrated.

The juice of $x$. badius was obtained by extraction of fruit-bodies dried, after slicing, in air blast dryer at $50-60^{\circ} \mathrm{C}$ during $12 \mathrm{~h}$ (for $10 \mathrm{~kg}$ samples) to $6 \%$ water content. Extraction of crushed material was performed in laboratory extractor Quickfit, at $50^{\circ} \mathrm{C}$ (temperature according to Zurakowski 1964).
The extraction efficiency was $500 \mathrm{ml}$ of extract from 500 g of dry material. Concentration was performed by vacuum distillation and by freezing technique described below. After pasteurization at $100^{\circ} \mathrm{C}$ during 30 minutes the concentrates were stored at $4^{\circ} \mathrm{C}$.

\section{Results and discussion}

All the studied fungi with lamellar hymenophore ( $T$. equestre, C. cibarius, R. alutacea, and A. mellea) were well adapted for juice pressing. The yield depended on the kind of press (basket or layer press) as well as on the state of the mushrooms (fresh or frozen). The highest yield $(67-75 \%)$ was obtained from frozen fruit-bodies pressed after disintegration and thawing on the layer press (Table 1 ). In this process the balance, shown in Table 2, makes about $75 \%$ of juice, about $20 \%$ of marc and about $5 \%$ losses, in comparison with $60 \%, 35 \%$ and $5 \%$, respectively from fresh fungi of second quality (broken).

About 35\% of the total dry weight of raw material was recovered in juice from frozen fungi, as compared with $26 \%$ recovery from fresh mushrooms (Table 3 ). The respective recovery values for acid and ester, which are compounds influencing the taste, were $50-$. $60 \%$ for frozen and $40 \%$ for fresh fungi.

The distribution of the nitrogen fraction, i.e. compounds representing the nutritive value of product, between juice and marc is shown in Table 4. Generally, with $60 \%$ yield of juice the marc retained about $70 \%$ of total $\mathrm{N}$ (together with chitin) and only about $60 \%$ 
Table 1. Yield of juice obtained from Trichozoma equestre using basket press and layer press.

\begin{tabular}{|ccc|}
\hline Sample & Basket press & Layer press \\
& & $\%_{\%}$ \\
\hline Mushrooms, fresh & $50-60$ & $60-67$ \\
Mushrooms, frozen & $60-65$ & $67-75$ \\
\hline
\end{tabular}

Table 2. Yield of juice obtained from fresh and frozen Tricholoma equestre using BücherGuyer press

\begin{tabular}{|cccc|}
\hline Sample & $\begin{array}{c}\text { Juice } \\
\%\end{array}$ & $\begin{array}{c}\text { Marc } \\
\%\end{array}$ & $\begin{array}{c}\text { Losses } \\
\%\end{array}$ \\
\hline Mushrooms, & & & \\
Broken $\varnothing>6 \mathrm{~cm}$ & 57.5 & 36.5 & 6.0 \\
& 63.6 & 31.5 & 4.9 \\
& 57.4 & 36.3 & 6.3 \\
on av. & 59.5 & 34.7 & 5.7 \\
Fresh $\varnothing$ 1.5-4.5 cm & 63.5 & 31.5 & 5.0 \\
& 67.5 & 30.3 & 2.2 \\
on av. & 65.5 & 34.5 & 0.0 \\
Frozen $\varnothing 1.5-4.5 \mathrm{~cm}$ & 65.5 & 32.1 & 3.6 \\
& 77.2 & 18.3 & 4.5 \\
& 72.2 & 23.3 & 4.5 \\
& 74.3 & 20.5 & 5.2 \\
& 74.5 & 20.7 & 4.8 \\
\hline
\end{tabular}

Table 3. Distribution of some components between juice and marc of Tricholoma equestre, Cantharellus cibarius and Xerocomus badius.

\begin{tabular}{|c|c|c|c|c|c|c|}
\hline \multirow[t]{2}{*}{ Mushroom } & \multirow[t]{2}{*}{ State } & \multirow{2}{*}{$\begin{array}{l}\text { Juice } \\
\text { yield } \\
\%\end{array}$} & \multicolumn{4}{|c|}{ Content in juice } \\
\hline & & & $\begin{array}{l}\text { Dry } \\
\text { weight } \\
\% \text { of } \\
\text { tot. }\end{array}$ & $\begin{array}{l}\text { Esters } \\
\% \text { of } \\
\text { tot. }\end{array}$ & $\begin{array}{l}\text { A c } \\
\text { Titrable } \\
\% \text { of tot. }\end{array}$ & $\begin{array}{l}\frac{i d s}{\text { Volatile }} \\
\% \text { of tot. }\end{array}$ \\
\hline \multirow[t]{2}{*}{ T.equestre } & Fresh & 59.0 & 26.0 & 38.7 & 41.3 & 38.3 \\
\hline & Frozen & 74.0 & 34.5 & 51.4 & 56.7 & 50.5 \\
\hline \multirow[t]{2}{*}{ C. cibarius } & Fresh & 56.0 & 26.5 & 40.6 & 38.0 & 40.3 \\
\hline & Frozen & 70.0 & 35.0 & 57.2 & 60.9 & 49.8 \\
\hline$x$. badius & $\begin{array}{l}\text { Dried- } \\
\text { ex- } \\
\text { tracted }\end{array}$ & - & 47.4 & 65.9 & 64.5 & 62.1 \\
\hline
\end{tabular}

Table 4. Distribution of nitrogen fractions between juice and marc of Tricholoma equestre. Juice yield $60 \%$.

\begin{tabular}{|c|c|c|c|c|c|}
\hline Product & Sample & $\begin{array}{l}\text { Cold } \\
\text { storage } \\
\text { months }\end{array}$ & $\begin{array}{c}\text { Total } \\
\%\end{array}$ & $\frac{\mathrm{R} \text { e c o v }}{\text { N Protein }}$ & $\frac{\mathrm{ery}}{\mathrm{NH}_{\%}-\mathrm{N}}$ \\
\hline \multirow{4}{*}{ Juice } & Mushrooms, & & & & \\
\hline & Fresh & - & 26.8 & 28.9 & 33.3 \\
\hline & Frozen & 0 & 29.0 & 31.3 & 36.1 \\
\hline & & 6 & 29.1 & 24.9 & 40.7 \\
\hline \multirow[t]{3}{*}{ Marc } & Fresh & - & 67.8 & 70.6 & 62.8 \\
\hline & Frozen & 0 & 65.3 & 68.8 & 59.0 \\
\hline & & 6 & 64.7 & 73.9 & 47.0 \\
\hline
\end{tabular}

of $\mathrm{NH}_{2}-\mathrm{N}$. This is reflected in the contribution of amine-N in the total nitrogen of pulp, juice and marc from fresh and frozen mushrooms ( $\mathrm{Table} 5$ ). In pulp the ratio of $\mathrm{NH}_{2}-\mathrm{N}$ to total $\mathrm{N}$ is about $70 \%$. In juice this increases to $86 \%$ from fresh and $95 \%$ from frozen fungi, and drops in marc to about $50 \%$.

The obtaining of juice from mushrooms with porous hymenophore (Xerocomus and Suillus) is more complicated. The pressing method was not effective for either fresh, frozen or dried mushrooms. Juice of a high organoleptic value could be obtained, however, by the extraction method, using as a raw material dried, crushed $x$. badius.

Several technological procedures were investigated for juice concentration using vacuum distillation and freezing techniques. In the former, juice was concentrated in a laboratory rotary glass evaporator, Unipan $319 \mathrm{~B}$ (vapor temperature $25^{\circ} \mathrm{C}$ ) 7-10 strength concentrate; in Quickfit extractor (bottom part) used as evaporator (concentration temperature $90^{\circ} \mathrm{C}$ ); in Titano laboratory evaporator (conc. temp. $\left.60^{\circ} \mathrm{C}\right) 4$ strength concentrate in the upper part and 12 strength in the bottom; Alfa-Laval Centritherm (conc. temp. $40^{\circ} \mathrm{C}$ ) 10 strength concentrate. The de -aromatization technique was used, and after storing the juice was reconstituted for organoleptic evaluation. All concentrates yielded juice of high organoleptic value. Unfortunately, the direct comparison of juices obtained from the different evaporators is not yet available owing to the small individual lots of raw material.

The freezing technique was also used but to a lesser extent and only for $T$. equestre juice, the ice being separated by centrifugation or decantation. The juice concentrates ( 7 strength) obtained by this method differed greatly from juice obtained by the thermal method. When vacuum distillation was used the taste and flavour characteristics of the concentrated juice and soups obtained were in general typical of mushrooms and close to the dried mushroom taste, the colour also being brown. In the freezing method the concentrates retained the green colour typical of the juice of this fungus and the very specific aroma of Tricholoma.

Table 5. Nitrogen fractions in pulp, juice and marc of Trichotoma equestre.

\begin{tabular}{|c|c|c|c|c|c|}
\hline \multirow[t]{2}{*}{ Sample } & \multirow[t]{2}{*}{ Product } & \multirow{2}{*}{$\begin{array}{l}\text { Cold } \\
\text { storage } \\
\text { months }\end{array}$} & \multirow{2}{*}{$\begin{array}{c}\text { Total N } \\
\text { g/100 g } \\
\text { d.w. }\end{array}$} & \multicolumn{2}{|c|}{$\mathrm{NH}_{2}-\mathrm{N}$} \\
\hline & & & & $\begin{array}{c}\text { g/100 g } \\
\text { d.w. }\end{array}$ & $\begin{array}{l}\% \text { of } \\
\text { total } \mathrm{N}\end{array}$ \\
\hline \multicolumn{6}{|c|}{ Mushrooms, } \\
\hline Fresh & pulp & - & 3.47 & 2.41 & 69.5 \\
\hline Frozen & & 6 & 3.35 & 2.40 & 70.9 \\
\hline Fresh & juice & - & 3.51 & 3.03 & 86.3 \\
\hline Frozen & & 6 & 2.99 & 2.73 & 95.0 \\
\hline Fresh & marc & - & 3.56 & 1.93 & 54.1 \\
\hline Frozen & & 6 & 4.82 & 2.51 & 52.0 \\
\hline
\end{tabular}


The soups obtained from both kinds of concentrate also differed greatly and needed separate qualification cards for organoleptic evaluation, both being of high organoleptic value (mean scores 4.0-4.5 units on the five-unit scale).

In Table 6 are listed the comparative organoleptic scores on the five-unit scale of the concentrated juices obtained from the different mushrooms by the same method of evaporation, and. in Table 7 the influence of storage for 4 months at $4^{\circ} \mathrm{C}$ on the sensory evaluation. The juice from $X$. badius was the best, followed by $T$. equestre and $C$. cibarius juices. The concentrate of $R$. alutacea was organoleptically unattractive; amelioration was achieved by mixing it with $x$. badius juice, which, in general, was the best material for raising the sensory value of juice concentrates of poor quality. The favourable effect of mixing different mushrooms in concentrate production has been reported earlier by Bötticher (194I, 1950), the only investigator who has worked on wild mushroom processing problems on a larger scale.

Table 6. Organoleptic scores of mushroom juice concentrates.

\begin{tabular}{|c|c|c|c|}
\hline \multicolumn{4}{|c|}{$\begin{array}{lc}\text { Concentration temperature } & 25^{\circ} \mathrm{C} \\
\text { Laboratory evaporator Unipan } 319 \mathrm{~B} \\
\text { Final extract content } & 30 \% \\
\text { Pasteurization } & 30 \mathrm{~min} \text { at } 100^{\circ} \mathrm{C} \\
\text { Storage } & 40^{\circ} \mathrm{C}\end{array}$} \\
\hline \multirow[t]{3}{*}{ Sample } & \multirow{3}{*}{$\begin{array}{l}\text { One-component } \\
\text { concentrate }\end{array}$} & \multicolumn{2}{|c|}{ Two-component concentrate } \\
\hline & & T.equestre & X.badius \\
\hline & & $1: 1$ & $1: 1$ \\
\hline Tricholoma equestre & 4.3 & - & 4.4 \\
\hline Xerocomus badius & 4.7 & 4.4 & - \\
\hline Cantharellus cibariu & 4.1 & 4.1 & 4.3 \\
\hline Russula alutacea & 2.9 & - & 3.8 \\
\hline Armillariella mellea & 3.8 & 3.0 & 4.0 \\
\hline
\end{tabular}

As was stated above, frozen mushrooms release juice with a higher efficiency than fresh ones (Tables 1 and 2), the extraction of valuable components also being better (Table 3, 4 and 5). As shown in Table 7, the favourable effect of freezing was reflected also in the sensory evaluation of concentrate from $T$. equestre as compared. with concentrate from fresh fungi. This supports the proposal of the combined processing method for $T$. equestre (Sobkowska \& Wokniak 1978). In Table 8 the chemical composition of concentrated as against single strength mushroom juices is given. After pasteurization at $100^{\circ} \mathrm{C}$ for 30 minutes the concentrates were stable chemically and organoleptically during the investigated four months of storage at $4^{\circ}$ c.

\section{References}

Bielozierski, A. \& Proskuriakow, N. 1954: Cwiczenia z biochemii róslin. - p. 241, Warszawa, PWRiL.

Bötticher, W. 1941: Die Pilzverwertung und ihre Zukunftsaufgaben. Ratgeben für Pilzfreunde, Grossküchen, Industrie und Handel. - Leipzig.

-"- 1950: Pilzverwertung und Pilzkonserwierung. $141 \mathrm{pp}$. München.

Sobkowska, E. \& Wozniak, W. 1978: Combined processing of Tricholoma equestre. - Karstenia 18 (suppl.). (This issue).

Tilgner, D.J. 1957: Analiza organoleptyczna zywnosci. - Warszawa, WPLis.

Zurakowski, M. 1964: Badanie nad procesem ekstrakcji grzybów (Investigations of the extraction process of mushrooms). - Przemysl Spozywczy 18: 26-31.

Table 7. Effect of storage ( 4 months, $+4^{\circ} \mathrm{C}$ ) on the organoleptic values of mushroom juice concentrates and obtained soups

\begin{tabular}{|c|c|c|c|c|c|c|c|}
\hline \multirow[t]{2}{*}{ Sample } & \multirow{2}{*}{$\begin{array}{l}\text { Storage } \\
\text { time } \\
\text { months }\end{array}$} & \multicolumn{3}{|c|}{ Concentrate from mushroams } & \multicolumn{3}{|c|}{ Soup from concentrate } \\
\hline & & Fresh & Frozen & Dried & Fresh & Frozen & Dried \\
\hline \multicolumn{8}{|l|}{ Tricholoma } \\
\hline \multirow[t]{2}{*}{ equestre } & 0 & 4.1 & 4.3 & - & 4.0 & 4.3 & - \\
\hline & 4 & 4.0 & 4.3 & - & 3.9 & 4.1 & - \\
\hline \multicolumn{8}{|l|}{ Cantherallus } \\
\hline \multirow[t]{2}{*}{ cibarius } & 0 & 4.1 & 4.1 & - & 4.1 & 4.2 & - \\
\hline & 4 & 4.0 & 4.0 & - & 4.0 & 4.0 & - \\
\hline \multicolumn{8}{|l|}{ Xerocomus } \\
\hline \multirow[t]{2}{*}{ badius } & 0 & - & - & 4.9 & - & - & 4.8 \\
\hline & 4 & - & - & 4.9 & - & - & 4.8 \\
\hline T.equestre & 0 & 4.1 & - & - & 4.2 & - & - \\
\hline C. cibarius) $)^{1: 1}$ & $11_{4}$ & 4.1 & - & - & 4.2 & - & - \\
\hline x.badius & 0 & - & - & 4.3 & - & - & 4.4 \\
\hline C.cibarius) $1:]$ & $11_{4}$ & - & - & 4.5 & - & - & 4.5 \\
\hline
\end{tabular}


Table 8. Effect of storage at $4^{\circ} \mathrm{C}$ on the chemical and organoleptic evaluation of mushroom juice concentrates.

\begin{tabular}{|c|c|c|c|c|c|c|c|}
\hline \multirow{2}{*}{\multicolumn{2}{|c|}{ Sample }} & \multirow{2}{*}{$\begin{array}{l}\text { Storage } \\
\text { time } \\
\text { months }\end{array}$} & \multirow{2}{*}{$\begin{array}{c}\text { Content } \\
\text { Extract } \\
\text { (ref.) } \\
\text { g }\end{array}$} & \multirow{2}{*}{$\begin{array}{l}\text { in } 100 \mathrm{~g} \\
\text { Titrable } \\
\text { acidity } \\
\text { ml } 0.1 \mathrm{n} \\
\mathrm{NaOH}\end{array}$} & \multirow{2}{*}{$\begin{array}{c}\text { of sample } \\
\text { Esters } \\
\text { mg } \\
\text { ethyl } \\
\text { acetate }\end{array}$} & \multicolumn{2}{|c|}{$\begin{array}{c}\text { Mean organoleptic } \\
\text { score }\end{array}$} \\
\hline & & & & & & Sample & Soup \\
\hline \multicolumn{7}{|c|}{ Tricholoma equestre, } & - \\
\hline & juice & & 3.3 & 19 & 158 & - & - \\
\hline & concentrate & 0 & 29.0 & 133 & 1216 & 4.1 & 4.0 \\
\hline & & 4 & 29.1 & 134 & 1184 & 4.0 & 3.9 \\
\hline & frozen & & 3.2 & 20 & 239 & 4.5 & - \\
\hline & juice & & 3.2 & 19 & 166 & - & - \\
\hline & concentrate & 0 & 30.0 & 140 & 1348 & 4.3 & 4.3 \\
\hline & & 4 & 30.0 & 140 & 1340 & 4.3 & 4.2 \\
\hline \multicolumn{7}{|c|}{ Contharellus cibarius, } & - \\
\hline & juice & & 3.4 & 16 & 288 & - & - \\
\hline & concentrate & 0 & 30.0 & 101 & 1985 & 4.0 & 4.0 \\
\hline & & 4 & 30.2 & 105 & 1933 & 4.0 & 3.9 \\
\hline & frozen & & 3.4 & 19 & 355 & 4.1 & - \\
\hline & juice & & 3.4 & 17 & 290 & - & - \\
\hline & concentrate & 0 & 30.0 & 98 & 2105 & 4.1 & 4.2 \\
\hline & & 4 & 30.1 & 102 & 2088 & 4.0 & 4.0 \\
\hline \multicolumn{8}{|c|}{ Xerocomus badius, } \\
\hline$\cdot$ & juice & & 4.0 & 12 & 192 & - & - \\
\hline & concentrate & 0 & 30.5 & 91 & 1386 & 4.9 & 4.8 \\
\hline & & 4 & 30.5 & 92 & 1378 & 4.9 & 4.8 \\
\hline
\end{tabular}

